\title{
Padveiligheid: Teologies-etiese opmerkings by enkele navorsingsprojekte in verband met die verkeersituasie in die RSA
}

\author{
PJT Koekemoer
}

\begin{abstract}
Road safety: Observations of a theological-ethical nature on a few research projects concerning the traffic situation in the RSA.

South Africa has an unacceptably high incidence of traffic deaths and serious injuries. Statistics feature among the highest in the world in relation to population; 15,3 percent per 100000 people.

This article suggests that all the churches in South Africa should be called upon to get involved by way of their own ecclesiastical methods and ways. Not only the functions of the church offices should be emphasised, but also the calling of each and every member of the congregation, including the youth. In this regard special attention is given to the theological-ethical contents of the message of the churches.
\end{abstract}

\section{INLEIDENDE OPMERKINGS}

\section{1 'n Stem uit die Nasionale verkeersveiligheidsraad}

In Beeld van Dinsdag 2 Februarie 1988 verneem ons van 'n nasionale streeksaamtrek van die Nasionale verkeersveiligheidsraad (NVVR). By hierdie geleentheid sou dr Louw Dreyer (vgl Dreyer 1986), direkteur van die NVVR daarop gewys het dat die verkeersonveiligheid nog nie die emosie en verbeelding van die groot massa padgebruikers in die RSA aangegryp het nie. Daar word baie aandag gegee aan vigs, malaria, vloed-en vliegrampe. In ons land sterf daagliks 25 mense in verkeersbotsings en 280 word ernstig beseer. Hy sou volgens Beeld verder gesê het dat, ondanks die konkrete werklikheid dat padvervoer Suid-Afrika se hele lewensbestaan op maatskaplike, ekonomiese en selfs politieke terrein oorheers, veiligheid in padverkeer nog nie die nodige erns, 
finansiering en besluitneming geniet nie. Dit is die NVVR se groot doelstelling dat hierdie toestand so gou as moontlik reggestel sal word.

In hierdie artikel wil ons die aandag daarop vestig dat verkeersveiligheid nie slegs 'n saak vir die landsowerheid en alle ander owerheidsinstansies is nie. Nie slegs die NVVR, die Departement van Vervoer, die Direktoraat Verkeersveiligheid ensovoorts dra die verantwoordelikheid om die breë publiek, alle volkere ingesluit, bewus te maak van die noodsaaklikheid van 'n veilige verkeersdeelname nie. Die hele privaatsektor, alle onderwysowerhede, ouerhuise, ja alle gemeenskapstrukture kom in sig. Die direkteur van die NVVR meld, volgens die berig, dat die formele onderwys tans deeglik kennis neem van die aard en omvang van verkeersveiligheid en die dringendheid van opvoedende onderwys en opleiding in verkeersveiligheid terdeë besef.

Ons sal graag hier wil byvoeg dat in die lig van die problematiese verkeersfeite wat ons in die volgende paragrawe gaan onderstreep, ook die kerke vanaf die vlakke van kerkregering tot by die kind in die kategese, via hul eiesoortige kerklike kanale, die verantwoordelikhede van padgebruikers, op grond van die liefde tot God en ons naaste moet gaan verkondig, leer en toepas. In ons teologiese fakulteite moet Verkeers-Etiek, in die lig van die slagting op ons paaie, 'n minder beskeie hoofstuk kry in die vak Teologiese/Christelike Etiek. Kerk en Teologie moet kennis neem van die huidige konkrete situasie van die verkeer in die Republiek van Suid-Afrika; in die verlede het verkeersproblematiek kwalik ons agendas gehaal. Is dit dan 'n 'kerksaak'?

\subsection{Medemenslikheid, nie humanisties nie maar teologies-eties}

Kerk en Teologie het alles met die verkeersituasie te doen omdat mense juis daar op unieke wyse mekaar ontmoet. Die verkeersman op sy motorfiets is slegs een rat in hierdie ontmoeting. In die lewensbeskouing van die Christen figureer die mens nie as 'n geïsoleerde individu nie. In die waan van die indiwidualisme van die vorige eeu het etiek byna uitsluitlik tot individuele etiek geword; baie min aandag is aan die gemeenskapslewe gegee. Die Bybel leer ons egter dat die mens nie ' $n$ 'atoommens' is nie. Die Bybelwoord dat dit 'nie goed is dat die mens alleen is nie' (Gen 2: 18), het wel in die eerste plek betrekking op die huwelik, maar kan tog ook in die algemeen geld. Die mens as 'n deur-God-geskape wese, God se 'beeld en gelykenis', God se 'verteenwoordiger', is kragtens sy skepping op gemeenskap aangelê. Medemenslikheid hoort tot die menslike eksistensie. Menswees beteken 'in 
die wêreld wees' sowel as 'met die ander wees' (vgl Brillenburg Wurth 1967: 64-67). Hier, met die ander, kom die verhouding met die ander ter sprake. Tweesaam is die mens. Dit impliseer in die saamwees die gebod van die liefde tot die naaste wat onafskeidelik aan die liefde tot God gekoppel is. Die naaste is die mens wat God, op watter manier ookal, op ons pad stel, ja ook op ons letterlike pad en straat. (Die gelykenis van die Barmhartige Samaritaan, Luk 10: 25-37). Kerk en Teologie staan nie op die basis van humanisme nie. Wanneer ons hier die liefde tot ons naaste, op grond van die liefde tot God voorop stel en as basis veronderstel, sluit dit die gestaltes van die liefde in, ook op die pad en op straat, veral die gestaltes van bedagsaamheid en verdraagsaamheid (geduld). Ons pleit dus vir humaniteit as medemenslikheid in die verkeersituasie nie op grond van die humanisme waar die mens sentraal gestel word en God van sy plek beroof word nie. Ware humaniteit is slegs vanuit die Woord moontlik. Christus is die waaragtige mens, die mensgeworde Woord. Die mens op ons pad, wie dit ookal mag wees, is die voorwerp van die liefde van God in Christus Jesus. Daarom het ons hierdie mens lief, respekteer ons hom/haar, tree ons bedagsaam en versigtig op. Sy lewe is kosbaar omdat dit ' $n$ gawe van God is, nie in die eerste plek omdat dit lewe, menslike lewe is nie. Alleen God is absoluut, nie die geskape werklikheid nie, ook nie die lewe nie. Ons verabsoluteer ook nie in die volgende bladsye die samelewingstrukture nie; ons het egter wel deeglik eerbied daarvoor. Ons het verder verseker 'n roeping om midde-in die strukture as Christene, volgens die gebod van God te lewe. Ons is ook geroepe om uit gehoorsaamheid aan die gebod van God, van tyd tot tyd, lynreg in te gaan teen die verwordinge wat vanweë die sonde sy kop telkens weer uitsteek, soos byvoorbeeld in die verkeersituasie.

\section{KERK EN TEOLOGIE MOET KENNIS NEEM OOK VAN EMPIRIESE GEGEWENS IN VERBAND MET DIE VERKEERSITUASIE IN DIE RSA}

Die kerk het veral gedurende die laaste dekades besef dat daar ook kennis geneem moet word van die resultate van wetenskappe buite die teologiese wetenskap. Die kerk kan hom byvoorbeeld kwalik uitspreek oor die maatskaplike probleme van vandag as die (kerklike) diens van barmhartigheid nie ook kennis neem van wat die sosiale wetenskappe oor die mens en sy probleme te sê het nie. Maatskaplike werkers en 
werksters in diens van die kerk moet daarom behoorlik gekwalifiseerd wees. Dit geld ook orreliste, mense wat die pastorale spreekkamers beman en kerklike administrateurs. Wanneer die Teologiese Etiek ter sprake kom en daar vakkundige uitsprake gemaak moet word oor byvoorbeeld kunsmatige inseminasie en orgaanoorplantings, kan die teologiese dosent nie sê dat hy niks met die uitsprake van die mediese wetenskap te doen het nie. Die kerk moet egter wel deeglik sorg dat die wese van sy boodskap nie deur enige ander wetenskap verdonkermaan sal word nie.

Die vak Teologiese Etiek in sy adviserende taak aan die kerk moet met albei voete vas op die aarde staan. Daar moet kundigheid in kerklike uitsprake lê as die kerk nie 'n swak figuur wil slaan in die wêreld nie. Vaaghede en algemene bewerings deug ten enemale nie. Ons stem daarom volkome saam met dr EL Smelik wanneer hy waarsku teen ' $n$ etiek wat in hoogdrawende woorde in die lug bly hang. Hy sê dat die etiek voortdurend besig moet wees met 'konkrete empiriese gegewens voordat daar konklusies getrek word' (Smelik \& Van Witsen 1964: 13). Hy raai die etiek aan om te gaan kers opsteek by veral die statistiek en die psigologie. Ook die regswetenskap is vanselfsprekend in die etiek van die verkeer onontbeerlik. Hierby kon hy die sosiale wetenskappe en die opvoedkunde ook bygevoeg het.

Omdat ons die wyse raad om eers te luister en dan te praat graag aanvaar, stel ons voor om in die grootste gedeelte van ons opstel 'n 'luisterende gemeente' te wees, ook na die stem van die empiriese wetenskappe, en om eers daarna teologies-kerklik te antword.

\section{DIE KONKRETE WERKLIKHEDE IN DIE SUID-AFRIKAANSE VERKEERSITUASIE IS HARDE WERKLIKHEDE}

Wie 'n besoek bring aan die kantore van die NVVR te Beatrixstraat 83, Pretoria, vind daar ' $n$ biblioteek vol informasie; hulle studieresultate van jarelange harde werk. Een enkele studiegids wat verwys na rapporte oor verkeersprobleme, verslae gepubliseer gedurende die jare 1972 tot 1986, verwys na nie minder nie as 356 van hierdie studiestukke (vgl Van der Walt, [1987]). Rakke vol boeke, tydskrifte en ander materiaal vertel 'n verhaal dat verkeersveiligheid die erns is van talle kundiges en verskeie instansies.

\subsection{Verkeersveiligheid. Enkele statistiese gegewens}

Ons gaan die statistiek heel eerste stel; dit toon immers feite aan wat deur niemand betwyfel kan word nie. Ons moet egter na hierdie syfers 
kyk sonder om haastig te wees. Onderstaande statistiek het ons persoonlik ontvang van die NVVR, wat meld dat die Sentrale Statistiekdiens behulpsaam was met die verskaffing van die gegewens. (Die syfers van 1987 was ten tye van die skrywe van hierdie artikel ongelukkig nog nie amptelik beskikbaar nie).

Veral vier groepe syfers is vir ons doel van belang: die getal ongevalle, die getal botsings, voetganger-ongevalle en die tipe voertuig betrokke.

\subsubsection{Ongevalle: 1982 tot en met 1986 (in die RSA)}

\begin{tabular}{|c|c|c|c|c|c|c|}
\hline Jaartalle & 1982 & 1983 & 1984 & 1985 & 1986 & $\begin{array}{c}\text { Jaarlikse } \\
\text { verandering } \\
\text { 1984. } \%\end{array}$ \\
\hline Gedood & 9154 & 9121 & 9621 & 8972 & 9343 & $4,1 \%$ \\
\hline Ernstig & 27087 & 27627 & 27795 & 25998 & 27302 & $5,0 \%$ \\
\hline $\begin{array}{l}\text { Geringe- } \\
\text { beserings }\end{array}$ & 68466 & 69709 & 72917 & 67665 & 75565 & $11,7 \%$ \\
\hline
\end{tabular}

Die jaar 1985 se aansienlike verbetering op 1984 word gevolg deur 'n agteruitgang ten opsigte van die getal sterfgevalle en ernstige- sowel as geringe beserings in 1986. Helaas!

Begripsverduideliking: (i) Onder 'sterfgeval' of 'gedood' word hier ook bygereken persone wat tot 3 maande na die botsing gesterf het. (ii) 'Ernstige besering' impliseer ' $n$ botsing waarna die persoon gehospitaliseer moes word of enigeen van die volgende beserings opgedoen het: frakture, ernstige kneusings, konkussie, inwendige beserings, ernstige snywonde en ernstige algemene skok wat mediese behandeling verg. (iii) 'Minder ernstige besering' dui op enige besering van minder ernstige aard, soos snye, kneusings, verstuitings en ligte skok.

\subsubsection{Getal botsings: 1982 tot en met 1986}

$\begin{array}{lrrrrrc}\text { Jaartalle } & 1982 & 1983 & 1984 & 1985 & 1986 & \begin{array}{c}\text { Jaarlikse } \\ \text { verandering } \\ 1984 . \%\end{array} \\ \text { Gedood } & 8047 & 7941 & 8376 & 7692 & 8075 & 5,0 \% \\ \text { Ernstig } & 18627 & 18653 & 18623 & 17034 & 17985 & 5,6 \% \\ \text { Gering } & 48200 & 49017 & 50538 & 46572 & 50855 & 9,2 \%\end{array}$

Die bemoedigende syfer van 1985 was van korte duur; 1986 toon weer 'n aanmerklike styging. 
3.1.3 Voetganger- en passasiersongevalle: 1986

Gedood Voetgangers

Passasiers

Ernstige beserings

4359

4984

Geringe beserings

7979

19323

TOTAAL

16363

59202

28701

83509

Die buitengewone hoë sterftes en beserings onder die voetgangers wat in botsings betrokke was, verg ' $n$ verklaring.

\subsubsection{Tipe voertuie betrokke: 1986}

Tipe voertuie

Passasiersvoertuie

Handelsvoertuie

Busse

Minibusse

Motorfietse

Trekkers

Groot totaal voertuie
Aantal voertuie betrokke in botsings

437326

106370

13025

33624

18103

6244

614692

\subsubsection{Opmerkings:}

- Passasiersmotors en ligte handelsvoertuie (bakkies) maak byna $70 \%$ uit van die totale getal voertuie.

- Motorfietsbotsings is buitengewoon hoog: Navorsing ten opsigte van 1983 toon dat alhoewel motorfietse in daardie jaar slegs 6,3 persent van alle motorvoertuie verteenwoordig het, het bestuurders van motorfietse 15,4 persent van die totale aantal bestuurdersterftes verteenwoordig! Die sterftes van motorfietsbestuurders per 10000 motorfietse was 12, terwyl daar slegs vier bestuurders per 10000 ander voertuie gesterf het (vgl Nel 1986a: 45).

Op die oorsake hiervan kan ons nie hier ingaan nie. Ons wil dit egter slegs meld dat dieselfde stuk navorsing pas genoem, noteer dat alkohol en dwelms ' $n$ groot rol in motorfietsbotsings speel en dat dit uit nasionale statistieke blyk dat motorfietsryers in meer as 'n derde van die sterftes gedurende 1983 'self en uitsluitlik vir die ongeluk verantwoordelik was, dit wil sê, sonder die toedoen of betrokkenheid van enige ander persoon of voertuig' (Nel 1986a: 42). Dit neem nie weg dat dit ook onomwonde duidelik is dat baie motoriste ' $n$ eienaardige, ongunstige, onredelike houding ten opsigte van motorfietse op die pad 
openbaar, 'n gesindheid wat nie in 'n Christelike gedragskode, maar ook nêrens, goed te praat is nie. Op sy beurt wek so 'n houding weer reaksie by die motorfietsryer (Nel 1986b: 1, 14, 15)!

\section{BYDRAENDE FAKTORE TOT VERKEERSBOTSINGS; MENSLIKE FAKTORE DIE GROOTSTE OORSAAK: 90,6 PERSENT}

\subsection{Die NOSS-navorsingsprojek, 1981 tot 1986}

Een van die mees omvattende navorsingsprojekte in verband met oorsaaklike faktore in verkeersbotsings, bekend as die Nasionale ongeluksteekproefstelsel (NOSS): finale verslag, is na byna 5 jaar van navorsing (1 Julie 1981 tot 31 Desember 1985) in Desember 1986 in sy finale vorm gepubliseer (Pienaar \& Upton 1986). Die skrywers van die finale verslag wil nie beweer dat hierdie steekproef waarin 1667 verkeersbotsings volledig ondersoek is (met die oog op die bepaling van die oorsaaklike faktore), ' $n$ presiese en akkurate weergawe is van die nasionale situasie nie. Daar is egter wel gepoog om so ver as moontlik die volgende doelstellings te bereik (Pienaar \& Upton 1986: 3):

- Om data te versamel aangaande die ernstigheidsgraad en aard van beserings opgedoen deur insittendes van voertuie, motorfietsbestuurders en -passasiers, fietsryers en voetgangers;

- om die faktore wat tot hierdie beserings bydra, te bepaal;

- om die eienskappe van padgebruikers wat tot padongelukke bydra, te bepaal;

- om te bepaal watter rol voertuigdefekte en 'n ongunstige padomgewing speel by die voorkoms van padongelukke; en

- om patrone, indien enige, in die voorkoms van oorsake vas te stel en die effektiwiteit van beskermende en teenmaatreëls te evalueer.

In 1584 van 1667 botsings kon bydraende faktore geïdentifiseer word. Dit is immers die belangrikste vraag by elke verkeersbotsing: Wat presies was die oorsaak of oorsake? 'n Botsing kan ook meer as een oorsaak hê. Dis wat geblyk het die geval te wees in genoemde 1584 ondersoeke. Nie minder nie as 4153 bydraende faktore is blootgelê, dit wil sê 2,62 faktore per botsing. Na samesprekings met die NVVR en na vergelyking met 'n soortgelyke Nieu-Seelandse projek, is daar op 'n bepaalde groepering van die groot getal bydraende faktore besluit. Drie 
hoofgroepe word onderskei: menslike faktore, pad- en omgewingsfaktore en voertuigfaktore.

\subsection{Menslike faktore}

(Vgl Pienaar \& Upton 1986: 11, 12. Let wel: Persentasies is bereken uit die totaal van 4253 oorsake, nie botsings nie).

- Onoplettendheid/onbedagsaamheid:

30,5 persent

- Verkeersoortredings.

- Volgafstande tussen voertuie:

1,7 persent

- Spoed te hoog vir toestande:

16,5 persent

- Ander oortredings van verkeersreëls:

11,1 persent

- Roekelose/nalatige bestuur:

- Onbekwaamheid vir bestuurstaak. (Sluit in ontoerei18,0 persent kende bestuursopleiding en onbevoegdheid om die voertuig in noodsituasies te hanteer):

7,5 persent

- Fisies/emosionele faktore:

- Bestuur onder invloed van alkohol of dwelms:

3,2 persent

- Fisisiese faktore: moegheid, lomerigheid, siektetoestande:

1,4 persent

TOTAAL 90,6 persent

\subsection{Faktore wat nie hier bespreek sal word nie}

- Pad- en omgewingsfaktore

- Die weer (reën, mis, wind, ensovoorts):

3,0 persent

- Geometriese padontwerp (ingenieursfaktore):

- Omgewing (swak beligting, ontoereikende padtekens, uitsig, ensovoorts):

2,8 persent

TOTAAL

1,2 persent

7,0 persent

- Voertuigfaktore:

Defekte wat tot botsings bygedra het:

2,4 persent

\subsection{Verteenwoordiging van bydraende faktore in die totaal van 1584 botsings}

In die voorafgaande is die menslike faktore bereken uit die totaal van 4153 oorsake. Hoe groot is die teenwoordigheid van die bydraende faktore in die totaal van 1584 botsings? Alkohol en dwelms vorm 
byvoorbeeld slegs 3,2 persent uit die totale aantal faktore wat ter sprake is. In die totale aantal botsings is dit egter klaarblyklik veel hoër: 8,5 persent. Hoe vergelyk dit met die ander faktore? Die resultate sien soos volg daaruit (Pienaar \& Upton 1986: 12):

- Onoplettendheid/onbedagsaaheid

80,0 persent

- Roekelose/nalatige bestuur

- Spoed te hoog vir toestande

47,2 persent

- Ander verkeersoortredinge

43,2 persent

- Onbekwaamheid vir bestuurstaak

29,1 persent

- Alkohol/dwelms

19,6 persent

- Weersomstandighede

8,5 persent

- Padontwerp

7,9 persent

- Voertuigfaktore

7,3 persent

6,2 persent

\subsection{Opmerkings}

- In 180 van 1584 verkeersbotsings waar onoplettendheid of onbedagsaamheid as 30,5 persent van die bydraende faktore aangegee word, was voetgangers die direkte oorsaak van die botsings. In effek is die persentasie nie 30,5 persent nie maar 26,2 persent.

- Ons het dit reeds gestel dat in ons teologies-etiese besinning oor ons verkeersproblematiek in die RSA, ons slegs aandag sal skenk aan die menslike faktore. Dit spreek eintlik ook vanself. Kerk en Teologie kan tog kwalik 'n sinvolle woord spreek oor die tegniese aspekte van pad- en voertuigontwerp. Dis sake vir ingenieurs.

\section{TEOLOGIES-ETIESE OPMERKINGS MET BETREKKING TOT DIE VERKEERSITUASIE IN DIE RSA}

\subsection{Gekonfronteer met harde, konkrete werklikhede}

Die statistiese gegewens verkry uit hoofsaaklik tegniese verslae wat as resultate van navorsingsprojekte gepubliseer is, het die ernstige graad van ons verkeersonveiligheid ondubbelsinnig onderstreep. Die kerke het gedurende 1986 te doen gekry met 9343 begrafnisse van mense wat op ons paaie en strate gesterf het. Gedurende hierdie jaar het die bedienaars van die Woord en ander ampsdraers asook kerklike werkers/werksters waarskynlik besoek afgelê by 27302 mense wat met ernstige beserings in hospitale opgeneem is, mense waarvan sommige 
permanent vermink in ' $n$ rystoel beland het. Al hierdie mense kon getel word. Sekere dinge kan egter nie getel of gemeet word nie: Die kerk het in sy pastorale gesprekke ook te doen gekry met mense wat vir ' $n$ korter of langer tyd geknel was met pyn, angs, kommer, slaaploosheid en moedeloosheid. Dit alles kan nie gemeet word nie, selfs nie in diepte beskryf word nie. Hoe kan die intensiteit van lyding, liggaamlik en geestelik, ooit gepeil word?

Voeg hierby die ekonomiese werklikhede, die finansiële krisisse waarin duisende mense beland het. Nadat die grootste assuransiemaatskappye en ander betrokke instansies saamgespan het om inligting te verskaf, verskyn in November 1987 'n tegniese verslag bevattende die kosteberekening van die botsings op ons paaie en strate gedurende die jaar 1986. Dit lees soos volg (Glass \& Hamilton 1987: 41, 42):

- Botsings waar slegs skade voorgekom het:

- Geringe botsings:

- Ernstige botsings:

- Botsings waarin mense gedood is:

R5 232 miljoen R10 040 miljoen R33 012 miljoen R183 571 miljoen

Die kerke het nie slegs met die mens as persoon te doen nie. Dit het ook alles te doen met die eiendom van die mens, met sy wins en met sy verlies.

\subsection{Riglyne vir die spreke van die kerke: Ses kanale}

Daar is Geesteswetenskappe wat bepaalde tegnieke het om die mens aan te spreek, byvoorbeeld die Sielkunde. Die kerke het nie 'tegnieke' nie. Die kerke het slegs die gesprek. Dit spréék die mens aan. Een van die sake wat ingeweef behoort te word in hierdie áanspraak, is verkeersveiligheid as 'n unieke ontmoeting van die mens en medemens in die verkeer te wees. Dit lyk vir ons of daar hoofsaaklik ses kanale is waardeur die kerk kan praat, kanale waarin die ampswerk van die kerk beklemtoon word, plus die werk van elke gemeentelid wat Sondag na Sondag die kerkdeure uitstap om onmiddellik daarbuite in hulle voertuie in $\mathrm{klim}$, midde-in die verkeer. Hierdie kanale is rééds daar. Die inligting moet slegs daar ingevoer word en dan deurgevoer word in 'n wye wêreld in. Dis die bedieninge van die kerke wat voortkom uit één bediening, die bediening van die Woord. Die een bediening neem verskeie gestaltes aan, maar dit moet altyd bediening van die Wóórd bly: 
- Die verkondiging deur die prediking.

- Die verkondiging deur die pastoraat, die herderlike sorg met huisbesoek.

- Die ouderlinge, die presbiteriaat, voer gesprekke.

- Die diakonale werksaamhede spreek die mens aan ook in hierdie besondere noodsituasie op pad en op straat.

- Groot menigtes (die gemeente) gaan vanuit die erediens die wêreld in, hulle wat die Woord gehoor het. Hulle moet op mekaar ag gee, sê die Bybel oor en oor. Hulle moet ook Maandag met ander praat oor wat hul Sondag gehoor het.

- Die verkondiging deur kategese: Die kerke gee ook onderrig, kategese. Kinders en kindertjies word geleer. Entoesiastiese jongmense moet die sout van die aarde word. Talle groot jeugsaamtrekke word telkens en telkens georganiseer. Kan verkeersveiligheid, so diep betrokke in menslike verhoudings, nie ook op die agendas kom nie? Dit gaan immers om geloofsléwe, om respek vir die mens en sy besittings as déél van ons lewensbeskouing, nie as 'n 'los' punt op ons agendas nie.

Dit is die goeie reg van elke kerk om hierdie kanale te hanteer op sy eie manier en volgens eie insigte. Om in te val by die groot landsorganisasie van verkeersveiligheid hoef die kerke niks, maar dan ook absoluut niks van hul eie karakteristieke manier van werk in te boet nie.

\subsection{Watter mens word aangespreek?}

Almal moet bereik word, vanaf die mees bedagsame bestuurder van 'n voertuig tot die mees roekelose jaagduiwel wat sperstrepe oorsteek, vanaf kinders wat pas 'tot die verstand gekom het' tot die hoogbejaarde wat nog sy voertuig kan bestuur en as voetganger besige strate oorsteek, vanaf die 'afskaffer' tot die alkoholverslaafde. Die 'brief' van die kerke moet afgelewer word by die 'adres' van almal met wie die kerke in aanraking kom.

En tog is daar een bepaalde teikengroep, ' $n$ besonder groot getal mense wat ten alle koste bereik moet word. Ons het gesien dat hulle soos volg beskryf kan word:

- Hulle is onoplettend en onbedagsaam.

- Hulle is roekeloos; dit is nalatig.

- Hulle is wetsongehoorsaam; verontagsaam verkeerswette. 
- Hulle drink-en-bestuur en as voetgangers is hulle onvas op hulle voete.

- Baie van hulle is ook onbekwaam om te bestuur.

Al hierdie mense moet bereik word deur die boodskap van die kerke. Waarskynlik sal die 'teikengroep' betrek moet word deur middel van die evangelisasiewerk van die kerke; hulle maak immers deur hul lewenswyse die indruk dat hulle buitekerklikes, kerkvervreemde mense is. Ook die sending van die kerk aan alle volke, die apostolaat, kom hier sterk op die voorgrond. Wie glo in die God wat die Vader is van Jesus Christus, die God van die Bybel, kan nie anders nie as om ook rég te lewe, volgens die wil van God.

\subsection{Wat moet die essensie wees van die boodskap van die kerke?}

\subsubsection{Die Heidelbergse Kategismus, Afdeling Sondag 40}

In sy padmisbruik word die mens ten diepste as die skuldige mens geteken, die mens as sondaar, die mens wat besig is om sy deur-Godgestelde doel te mis deur sy roekelose handeling om sy naaste dood te ry. In die verkeersituasie, hier en nou, kan die reformatoriese kerke weinig verbeter op wat reeds eeue gelede ingeskryf is in ' $n$ belydenisstuk van 'n groot deel van die Christendom, die Heidelbergse Kategismus. Op die keper beskou, dek slegs één Sondagafdeling die elemente wat in 90,6 persent van die oorsaaklike faktore van verkeersbotsings gediagnoseer is: onoplettendheid, roekeloosheid en wetsongehoorsaamheid. Wanneer die reformatoriese kerke ook aan hierdie bepaalde mens vra wat God van hom eis in die sesde gebod, die gebod oor moord (doodslag), behoort hy te antwoord dat hy nie slegs ' $n$ ander mens nie mag vermoor, doodsláán nie. Nee, so skraal kon die kerk die antwoord nooit verstaan nie. Die kerk formuleer sy standpunt só (Die drie formuliere van eenheid: 59,60 ):

Afdeling Sondag 40, vraag en antwoord 105

Vraag: Wat eis God in die sesde gebod?

Antwoord: Ek mag nie self en ook nie deur iemand anders my naaste onteer, benadeel, haat, wond of doodmaak nie. Ek mag dit nie met my gedagtes, woorde of gebare doen nie en nog minder met die daad (a). Ook moet ek alle wraaksug laat vaar $(b)$ en verder mag ek myself nie kwaad aandoen of moedswillig in gevaar begewe nie (c). Daarom dra die owerheid dan ook die swaard om doodslag te weer (d). 
(a) Matteus 5: 21, 22; 26: 52; Genesis 9: 6

(b) Efesiërs 4: 26; Romeine 12: 19; Matteus 5: 25; 18: 35.

(c) Romeine 13: 14; Kolossense 2: 23; Matteus 4: 7.

(d) Genenis 9: 6; Eksodus 21: 14; Matteus 26: 52; Romeine 13: 4.

Vraag en antwoord 106

Vraag: Word in hierdie gebod net van doodslag gepraat?

Antwoord: Deur doodslag te verbied, leer God ons dat Hy nyd (a), haat (b), woede (c) en wraakgierigheid verafsku en dit alles as doodslag beskou (d), omdat dit die wortel van doodslag is.

(a) Spreuke 14: 30; Romeine 1: 29.

(b) 1 Johannes 2: 11.

(c) Jakobus 1: 20; Galasiërs 5: 19-21.

(d) 1 Johannes 3: 15.

Vraag en antwoord 107

Vraag: Het ons die gebod gehoorsaam as ons maar net nie ons naaste doodmaak, soos hierbo gesê is nie?

Antwoord: Nee, maar wanneer God nyd, haat en woede verbied, beveel Hy ons daarmee om ons naaste soos onsself lief te hê (a). Ons moet teenoor hom geduldig, vredeliewend, sagmoedig, barmhartig en vriendelik wees (b), alles wat hom kan benadeel, probeer voorkom (c) en selfs aan ons vyande goed doen (d).

(a) Matteus 22: 39; 7: 12; Romeine 12: 10.

(b) Efesiërs 4: 2; Galasiërs 6: 1, 2; Matteus 5: 5; Romeine 12: 18; Lukas 6: 36; Matteus 5: 7; 1 Petrus 3: 8; Kolossense 3: 12.

(c) Eksodus 23: 5 .

(d) Matteus 5: 44, 45; Romeine 12: 20.

(Opmerking: Aangesien hierdie artikel nie in die eerste plek 'n eksegetiese studie is nie, gaan ons hier nie in op eksegetiese probleme wat by die geldigheid van die Skrifbewys moontlik ter sprake gebring kan word nie.)

\subsubsection{Gesigspunte wat ter sprake moet kom in die kerkwerk}

In die uitleg van hierdie Sondagsafdeling sal die volgende elemente toegelig moet word:

- Die breëre betekenis (sinekdogeïese karakter) van die sesde gebod.

- Liefde tot ons naaste. 
- Die Bybelse konsep van die mens se lewe met verwysing na die beeld van God.

- Selfsug en gebrek aan verantwoordelikheidsbesef.

\subsubsection{Die breëre betekenis (sinekdogeiese karakter) van die sesde gebod}

'n Sinekdogee is ' $n$ stylfiguur waarby 'n geheel deur 'n deel aangedui word (vgl Schoonees et al 1965: 751). Byvoorbeeld: Om te moor is slegs 'n deel van die vergryp wat moontlik is. Selfmoord, maar ook sogenaamde 'aktiewe eutanasie' deur 'n medikus, is ook verbode. Om byvoorbeeld onder invloed van alkohol en/of roekelose bestuur iemand dood te ry, is nie 'n minder ernstige wandaad nie. Die ander gebooie van God moet ook so breed verstaan word. Eerbied teenoor jou vader en moeder impliseer om álle gesagsinstansies gewigtig te ag. God gee aan ons slegs die hooflyne. Die Kategismus onderskei nog fyner. Ek mag my naaste nie onteer, benadeel, haat of wond nie, nie met die daad nie, ja selfs ook nie met my gedagtes nie. Mens dink verder onmiddellik aan Christus se uitleg van die wet op egbreuk (hoerery). Nie slegs die daad is sondig nie; elkeen wat net na 'n vrou kyk om haar te begeer, het reeds in sy hart met haar egbreuk gepleeg (Matt 5: 28). Die kerklike uitleg van die sesde gebod, hier in die Kategismus, is derhalwe volkome legitiem.

\subsubsection{Naasteliefde}

Indien ons die tweede Tafel van die wet van God sou gaan isoleer van die eerste Tafel, het ons teologies-eties platgeval, beland in blote humanisme, noem dit horisontalisme. Dis nie meer teo-logie nie, dis antropo-logie, dit word 'social gospel'. Met die liefde wat ons behoort te beoefen teenoor ons naaste, kan ons nie begin nie; ons moet wel daarby uitkom. Nou moet ons egter ook nie redeneer en sê dat dit derhalwe duidelik is dat die kerk moet begin met 'n oproep dat óns God moet liefhê nie. Beginpunt is nie óns nie! Nie óns het God eerste liefgehad nie. Ons het lief omdat Gód ons éérste liefgehad het (1 Joh 4: 19). Die bekende Johannes 3: 16 moet dus voorop staan: 'So lief het God die wêreld gehad ...'

Die liefde van God het Hy geopenbaar in Jesus Christus. Sy liefde moet egter beantwoord word. In dankbaarheid vir wat God in Christus Jesus gedoen het, wil hierdie mens God liefhê van Christusweë. (Teologiese Etiek is Dankbaarheids-Etiek). Bied die Johannesbriewe nie by uitnemendheid aan ons ' $n$ refrein van God se liefde vir ons en ons 
liefde vir Hom én ons naaste nie? Ons het hierbo met die gebooie begin. Johannes sê dis reg so: 'As ons die gebooie van God gehoorsaam, weet ons daaraan dat ons Hom ken. lemand wat sê: "Ek ken Hom," maar nie sy gebooie gehoorsaam nie, is ' $n$ leuenaar en die waarheid is nie in hom nie...' (1 Joh 2: 3-5).

Die begrip 'naasteliefde' word deur Heyns saamgevat in 'n aantal kontekstuele perspektiewe waarbinne die naaste geplaas moet word. Ons verwys na slegs twee van hierdie perspektiewe:

- Die nasionale konteks: Hier is die naaste allereers en by voorkeur die volksgenoot. Die Ou Testament gee hieroor verskillende uitsprake. Teen hierdie agtergrond moet die optrede van die priester, die leviet en die (barmhartige) Samaritaan verstaan word.

- Die ekklesiologiese konteks: In die gemeente moet die ware en werklike gemeenskap van die gelowiges plaasvind. (Heyns 1967: 104):

- Hulle moet op mekaar ag gee: 1 Tessalonisense 5: 14; Hebreërs 12: 14, 15; Judas 22: 23; Galasiërs 6: 1; Handelinge 20: 28.

- Hulle moet bid vir mekaar: Jakobus 5: 16; 1 Johannes 5: 16; Romeine 15: 30.

- Hulle leef sáám met mekaar: Romeine 12: 15; 13: 8; Galasiërs 6: 2; Filemon 2: 18; Hebreërs 13: $3 ; 2$ Korintiërs 7: 3.

- Hulle moet mekaar dien: Johannes 13: 14; Titus 3: 8; 1 Petrus 4: 10; Galasiërs 6: 10.

- Hulle moet mekaar liefhê: 1 Johannes 4: 12; 1 Korintiërs 13; Hebreërs 13: 1; Romeine 12: 10, 16; Matteus 5: 43.

- Hulle moet gasvryheid beoefen: Romeine 12: 13; Hebreërs 13: 2; 1 Petrus 4: 9.

- Hulle moet vrede hou met mekaar: Romeine 14: 19; Romeine 12: 18; 1 Tessalonisense 5: 13.

- Hulle moet mekaar vermaan: 1 Tessalonisense 5: 14.

- Hulle moet onderlinge vriendelikheid beoefen: Filemon 4: 5; 1 Petrus 3: 8; Efesiërs 4: 32.

- Hulle moet met ontferming vervul wees: Efesiërs 4: 32.

- Hulle spreek die waarheid met mekaar: Efesiërs 4: 25.

- Hulle moet 'n voorbeeld vir mekaar wees: Filemon 3: 17.

- Hulle aanvaar mekaar: Romeine 14: 1; 15: 7.

Naasteliefde, veral in die konteks van sosiaal-maatskaplike perspektiewe, is op natuurlike gronde haas onmoontlik. Hoe kan ek tog 
roekelose jaagduiwels en besope, strompelende voetgangers as my naaste beskou en as sulks ook behandel?

Naasteliefde is alleen in Jesus Christus, deur die Heilige Gees, moontlik. Selfs hier in die konkrete verkeersituasie!

\subsubsection{Die Bybelse konsep van die mens se lewe}

Wat dink die onoplettende, nalatige, wetsongehoorsame, onbekwame en dranklustige voertuigbestuurders van die lewe van hulle medepadgebruikers? Skynbaar niks, bloedweinig! Maar hoe behoort ' $n$ mens wat bely dat hy/sy in God glo, die lewe van die mens te evalueer?

BJ Engelbrecht wys daarop, nadat hy enkele eksegetiese opmerkings gemaak het, dat die Bybel, en veral die sesde gebod, 'die lewe' sien as 'n gawe van God wat ons in dankbaarheid moet aanvaar en sinvol moet bestee. Die lewe is as ' $n$ gawe van God iets waaroor slegs Hy beskik. Ons mag die lewe dus nooit eiewillig in ons hand neem om dit uit te wis en te verspeel nie. Ek is derhalwe nie die 'baas' van my eie lewe nie. Die mens is geskep deur God, na sy beeld. Jesus verduidelik met betrekking tot die vraag oor die belasting dat aan die keiser gegee moet word wat die keiser toekom. Hy doen dit omdat die beeld van die keiser op die muntstuk verskyn. Derhalwe sê Jesus: Gee dan ook 'aan God wat aan God behoort' (Matt 22: 15-22).

God, as Skepperheer, skenker van die lewe aan die mens, wil hierdie lewe ook beskut: 'Wie die bloed van ' $n$ mens vergiet, deur ' $n$ mens sal sy bloed vergiet word. God het die mens gemaak as sy 'verteenwoordiger' (Nuwe Afrikaanse vertaling - Gen 9:6). Die ou vertaling lees hier dat God die mens na 'sy beeld' gemaak het. Daarom moet ons eerbied hê vir die menslike lewe. Ook Karl Barth wil sy begronding van eerbied vanuit die sesde gebod verstaan, van waaruit hy die lyn deurtrek tot die bevestiging van die gebod in die Nuwe Testament. Hierdie lewe wil God ook beskut; geen bloedvergieting van God se verteenwoordiger mag plaasvind nie; ook nie op ons paaie nie.

Dit moet egter duidelik gestel word dat die skepsel (skepping) van God nêrens in die Bybel verabsoluteer word nie. Nie die lewe as sulks is die spil waarom alles draai nie. Albert Schweitzer se lewensleuse van 'Ehrfurcht vor dem Leben' ter wille van die lewe self, kan nie aanvaar word nie, omdat God alleen absoluut is. Mens kan onderskryf wat Barth sê: 'Wo bei Schweitzer das Leben steht, da steht bei uns Gottes Gebot'; dus uitdruklike eerbied en hoë agting vir die lewe as gawe van God en nie verabsolutering nie! Hierdie eerbied moet verbind word met die gebod van die naasteliefde. Doen aan jou naaste wat jy aan jouself 
gedoen wil hê, ten alle tye, op alle plekke en onder alle omstandighede. Ook op ons paaie!

\subsubsection{Selfsug en gebrek aan verantwoordelikheidsbesef}

Mens kan met Smelik (Smelik \& Van Witsen 1964: 38-40) saamstem wanneer hy betoog dat gebrek aan verantwoordelikheidsbesef voortvloei uit' $n$ ongebreidelde egoisme. Selfbeskerming, selfkennis, selfaanvaarding en selfversorging is Christelike deugde. Selfsugtigheid staan egter lynreg teenoor naasteliefde. Dit druis in teen die totaliteit van die ganse Bybelse boodskap. Heyns stel dit skerp: "n Liefde wat sy diepste grond vind in ' $n$ eksklusiewe gerigte vertoon op die eie persoon, is ' $n$ demoniese liefde - en waar 'n demoniese liefde heers, is daar geen ruimte vir liefde tot God of liefde tot die naaste nie' (Heyns 1982: 251, 259). Vanweë die sondige natuur van die mens land hy in die motief van eksklusiewe eiebelang, ook in die verkeersituasie.

Die egosentrisiteit waaraan ander mense onderwerp word deur die haastigheid (gejaagdheid) van 'n enkele bestuurder, kan nie met genoeg woorde eties afgekeur word nie. Dit kanselleer alle verantwoordelikheidsbesef. Dis die vrug van 'n ongebreidelde selfsug, lynreg teenoor die Woord van God. Aangesien hierdie verkeersgedrag daagliks uit te ken is, het ons hier dus ook daagliks te doen met ' $n$ publikasie, nie van ' $n$ verkeerssiekte nie, maar van sonde, want selfsug is sonde. Die selfsugtige mens en hy alleen is die middelpunt, en almal moet voor hom padgee. Hy dink dat die verkeer bestem is om hom alleen te dien en wel op daardie oomblik dat hy daaraan behoefte het. Dit kan hom nie skeel wat voor hom plaasvind nie. Die kriminoloog, Kurella, sê 'n misdadiger se misdaad is 'die soewereiniteit van die ek en die oomblik' (vgl Smelik \& Van Witsen 1964: 39). Die misdaad van 'n verkeersegoïs laat, indien dit sonder gevolge bly, geen spore na nie. Daardeur word aan sulke misdadigers geen aandag gegee nie en het hy/sy ontsnap uit die hande van die gereg. Hierdie egosentriese mens wil prinsipieel en prakties met sy medemens en die gereg geen rekening hou nie. Verkeerstekens erken hy slegs met teësin omdat dit hom in sy 'vryheid' beperk. Hy sal dit ook slegs nakom waar kontrole hom kan inhaal. Teen finansiële skade is hy verseker! Selfs sy eie lewe is verassureer! Wat skeel dan nog? Op die pad en op straat wil hy alleen domineer. In egosentriese waan is hy vasgevang en op elke mens wat voor hom is, veral op die pad, is hy jaloers. Elke ander mens voor hom is sy konkurrent. As hy nie 'n oop pad voor hom sien nie, is hy 
verontwaardig want alles in die wêreld, ook die verkeersweë, is daar om hom te dien.

Die een ding wat ons by hierdie mens nie sal vind nie, is selfbeheersing. Wat is selfbeheersing? Selfbeheersing is die moed om nie ' $n$ verwytende en kwetsende woord te spreek nie, nie 'n vernietigende daad te verrig nie. So word die krag van die gees beheer èn versterk, en die adel van persoonwees bekend (vgl Heyns 1982: 368).

Verantwoordelikheidsbesef? Nee, as mens niemand anders konsidereer nie, nie raaksien nie, teenoor wie sal jy jou dan verantwoord? Die 'soewereiniteit van die ek en die oomblik' verdof hierdie mens se hart en verstand so totaal en al, dat hy nie weet van 'n antwoord op die waarom van sy roekeloosheid nie; nie aan die gereg nie en ook nie aan God is hy verantwoording verskuldig nie! Hy is onverantwoordelik.

Hierdie mens is die voorwerp van die bearbeiding van die Christelike kerk!

\section{Literatuurverwysings}

BARTH, K 1951. Dogmatik, 111/4. Zollikon: Evangelischer Verlag.

BRILLENBURG WURTH, G 1967. Christelike sedeleer, Vertaal deur BJ Engelbrecht. Pretoria: Van Schaik.

DREYER, LA 1986. Die opvoeding en opleidingstaak van die Nasionale Verkeersveiligheidsraad. DD-proefskrif, PU vir CHO.

Die drie formuliere van eenheid: Die ekumeniese belydenisskrifte. Voorlopige proefvertaling van die Interkerklike Kommissie. Pretoria: NG Kerk-Uitgewers.

ENGELBRECHT, BJ. Die wet van God. Pretoria: HAUM.

GLASS, RD \& HAMILTON, CC 1987. An estimate on the cost of road traffic accidents in South Africa, 1986. Technical report RT/104. Pretoria: CSIR.

HEYNS, JA 1967. Die kerk as diens aan die koninkryk: Annale, Universiteit van Stellenbosch. Vol 32, Serie B, No 1.

HEYNS, JA 1982. Teologiese etiek, Deel 1. Pretoria: NG Kerkboekhandel.

KOEKEMOER, PJT 1980. Die teologies-etiese probleem van die eutanasie met verwysing na die mediese etiek, C54. Sovenga: Universiteit van die Noorde.

NEL, PW 1986. Houdings ten opsigte van motorfietse in verkeer. Tegniese verslag NVVR/15. Pretoria: NIVP, WNNR.

NEL, PW 1986. Motorfietsongelukke in Suid-Afrika: 'n Opvolgstudie. Tegniese verslag RV/22. Pretoria: NIVP: WNNR.

ODENDAAL, FF, SCHOONEES, PC, SWANEPOEL, CJ, DU TOIT, SJ \& BOOYSEN, CM 1965. Verklarende handwoordeboek van die Afrikaanse taal. Johannesburg: Voortrekker.

OOSTHUIZEN, GC, SHAPIRO, HA \& STRAUSS, SA sa. Euthanasia. (HSRC Publication 65.)

PIENAAR, I \& UPTON, AH 1986. Nasionale ongeluksteekproefstelsel: Finale verslag. Tegniese verslag NVVR/17. Pretoria: NIVP, WNNR.

SMELIK, EL \& VAN WITSEN, IRM 1964. Ethiek van het verkeer. Nijkerk: Callenbach.

VAN DER WALT, C [1987]. Nasionale Verkeersveiligheidsraad. Ongepubliseerde navorsingsgids 1972-1986. 